\title{
Proglacial streams and their chronology in the glacier forefields of the Himalayas
}

\author{
Gerrit Tombrink \\ Institute of Geography, University of Göttingen, Goldschmidtstrasse 5, 37077 Göttingen, Germany
}

Correspondence: Gerrit Tombrink (g.tombrink@mailbox.org)

Relevant dates: $\quad$ Published: 10 September 2018

How to cite: $\quad$ Tombrink, G.: Proglacial streams and their chronology in the glacier forefields of the Himalayas, E\&G Quaternary Sci. J., 67, 33-36, https://doi.org/10.5194/egqsj-67-33-2018, 2018.

Supervisors: Matthias Kuhle $\dagger$, Daniela Sauer, Jürgen Ehlers Dissertation online:

http://hdl.handle.net/11858/00-1735-0000-002E-E317-A

The aim of this investigation was to develop a classification of glaciofluvial landforms and to identify a general sequence of these forms in the glacier forefields of the Himalayas. The intention behind this effort was to provide a standard sequence of typical glaciofluvial landforms that can serve as a tool for establishing relative chronological frameworks of fluctuations of glaciers in cases in which the preservation of moraines does not allow for direct determination of the former extents of glaciations. Thus, this research aimed at establishing a standard sequence of landforms that shows a climatic-genetic dependence on recent and historical glacier fluctuations during the Holocene in the study areas of Khumbu Himal (central Eastern Himalayas; Fig. 1a) and Pangong Tso (Western Himalayas; Fig. 1b). An empirical approach, including systematic analyses at the micro-, meso-, and macroscale (Schumm, 1991) of the main study area in Khumbu Himal, allowed such a standard sequence to be identified. This systematic multi-scale approach also proved suitable for the proglacial streams in the semi-arid region near the Pangong Tso southwest shore, which was used to identify convergences and divergences of landforms.

The methods that finally allowed for the establishment of the standard sequence of glaciofluvial landforms included geomorphological field techniques that were applied in two field campaigns in 2012 and 2013, sedimentological analy- sis, satellite image studies, and photo-panorama evaluations. Combination of these methods allowed for the distinguishing of divergent channel-reach morphologies (Montgomery and Buffington, 1997), glaciofluvial terraces, gravel deposits (sandur), sequences of proglacial stream landforms, and longitudinal stream profiles in the study areas of the Himalayas. The influencing factors of the streams, such as geological processes (e.g., tectonic deformation), slope processes (e.g., avalanches, debris flows), climatic processes (e.g., precipitation), and fluvial processes (e.g., glacial lake outburst floods (GLOFs), river inflows), were considered. The roles of these factors were clarified using additional field surveys in tributary valleys.

Microanalysis. In the glacier forefields, proglacial streambed morphologies show a downstream change from cascades into step-pool sequences. Based on these changing morphologies, early and late stages of streambed evolution were reconstructed. This approach allowed for relative classification of the beds of the proglacial streams in Khumbu Himal into early and late stages of streambed evolution. The basal tills underneath the streambeds were rarely deposited during Late Glacial to Neoglacial stages (IV-'VII), but mostly during historical glacier stages (VII-XI) to the recent (XII) glacier stage (glacial stages according to Kuhle, 2005), and stages from 1980 onwards (glacial stages according to Racoviteanu and Bajracharya, 2008). In the proglacial streams at Pangong Tso, the streambed was relatively classified into several late stages of streambed evolution. In these study areas, the basal tills underneath the streambeds were 


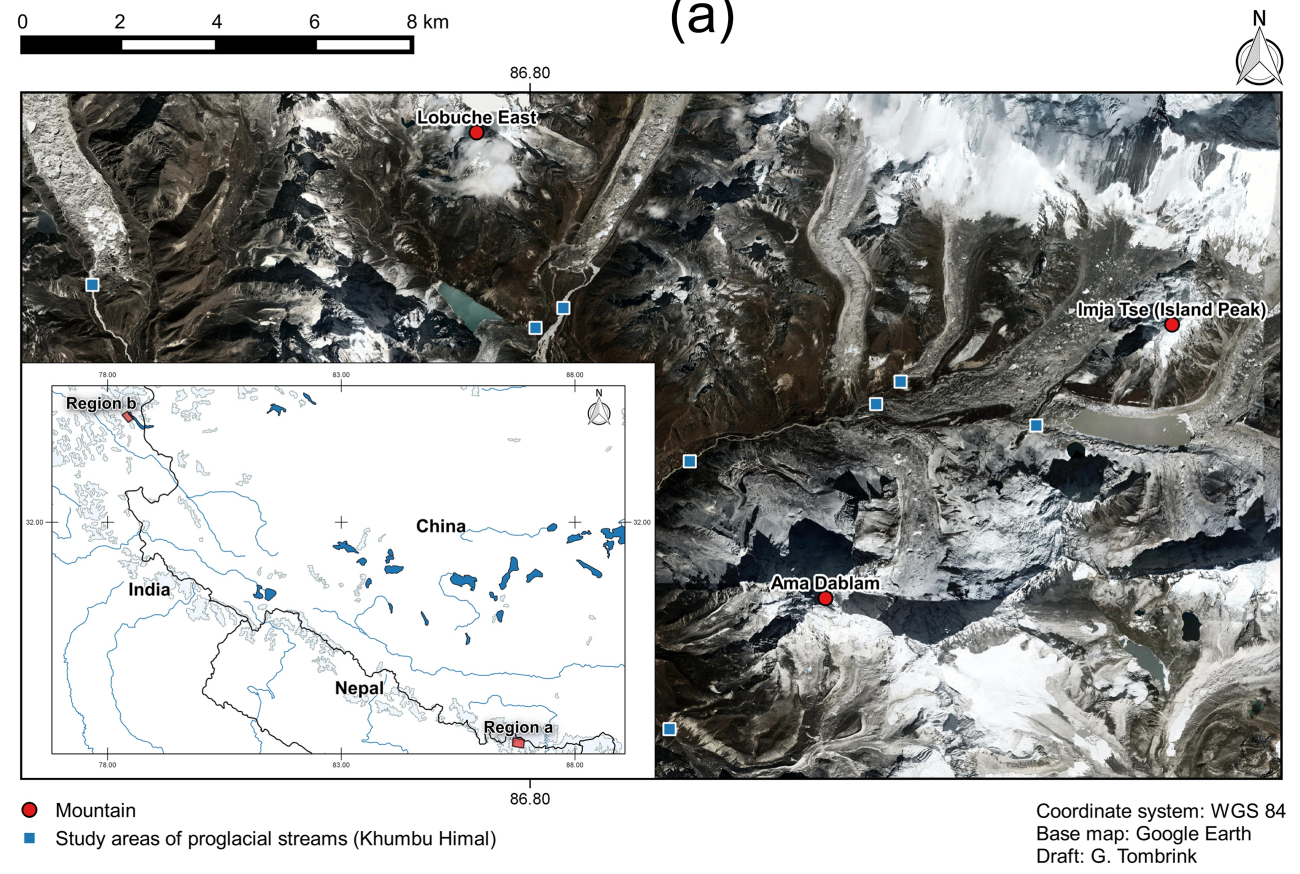

(a)

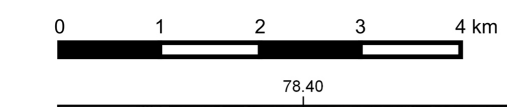

(b)

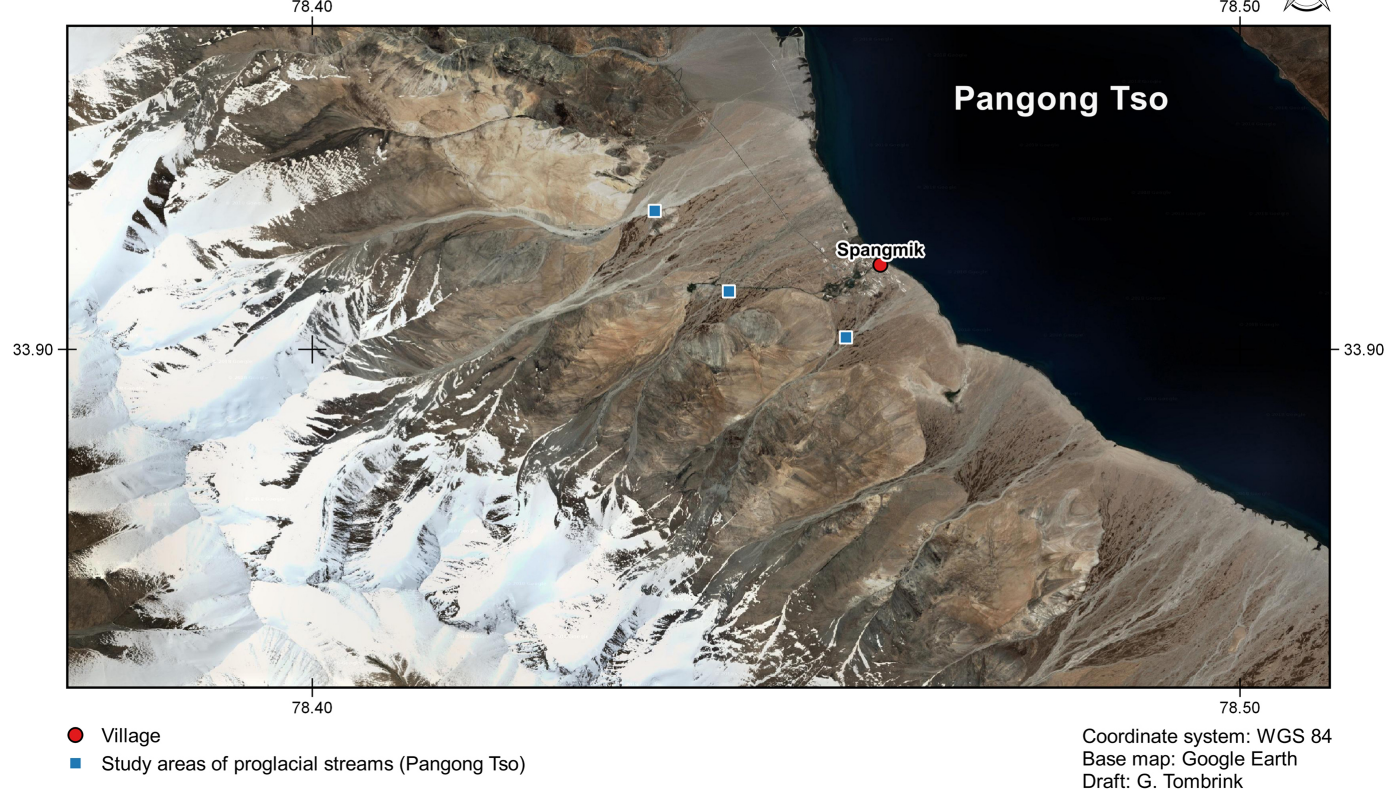

Figure 1. Map of the study areas in Khumbu Himal (a) and Pangong Tso (b).

deposited during the Sirkung glacier (IV) to the Nauri glacier stages (V) (glacial stages according to Kuhle, 2013). Steppool sequences were mapped much further downstream of the channel-reach morphologies in the Khumbu Himal. Thus, a relative chronology of the streambeds was clearly ascertained.

Mesoanalysis. At least four terraces were distinguished in the upper proglacial catchment areas in the Khumbu Himal.
Their number increased up to five (Imja Khola main stream) and six (lower Nare Drangka stream) further downstream. The lowermost terrace orders (one to four) were attributed to recent and historical glacier stages, including their meltdown phases. The higher terrace orders (five to six) were attributed to historical glacier stages, including meltdown phases during the Holocene (glacial stages according to Kuhle, 2013). However, these higher terraces may be influenced by vari- 


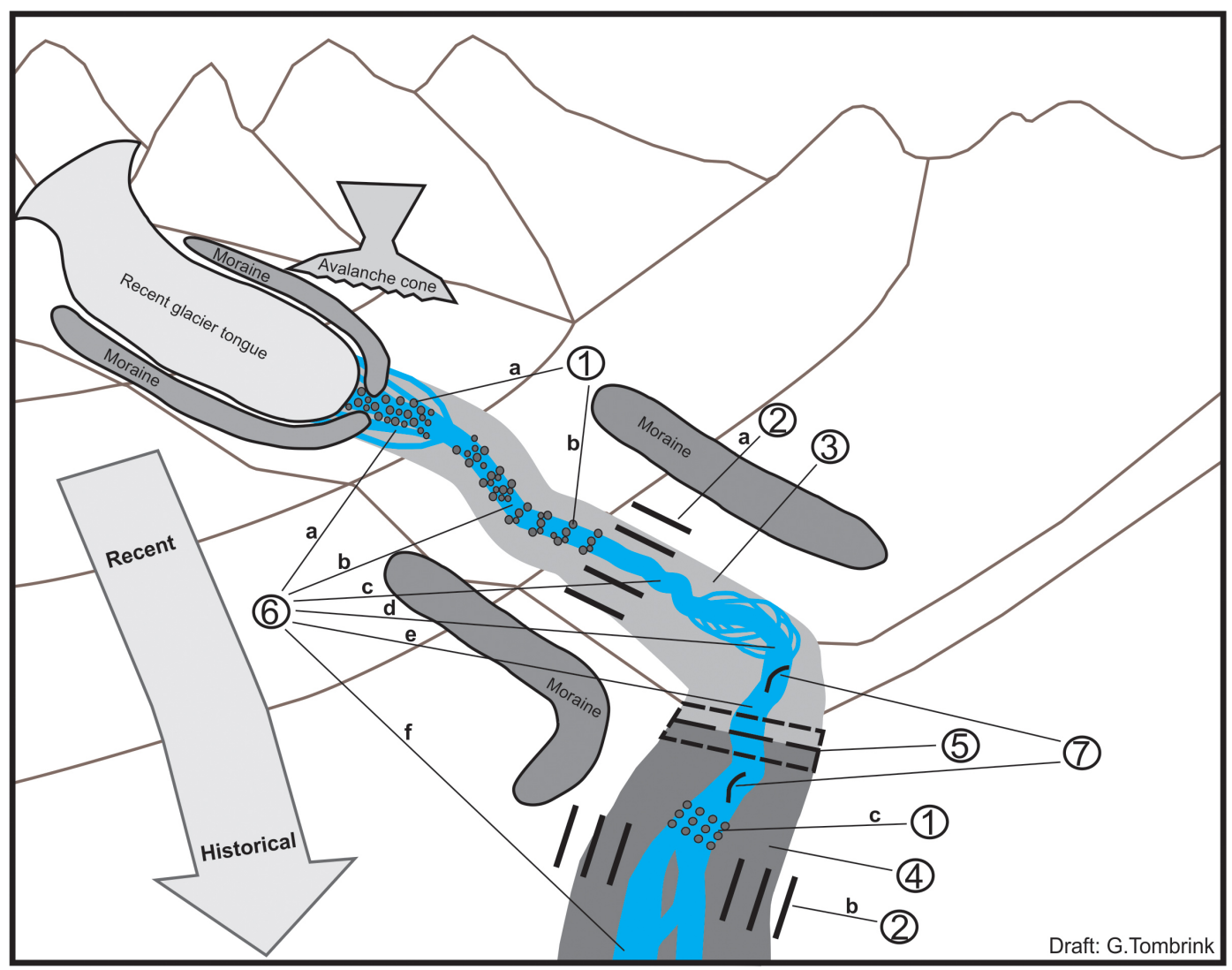

Figure 2. Characteristics of glaciofluvial and fluvial landforms in the glacier forefields of the Himalayas. 1: Horizontal-vertical, chronological sequence of (a) cascades and their (b) stages of evolution to (c) step-pool streambeds. 2: Glaciofluvial terrace sequences of (a) four terraces and (b) up to six or more terraces. 3: Upstream-located recent sandurs. 4: Downstream-located historical sandurs. 5: Vertically nested recent and historical sandurs. 6: Horizontal-vertical proglacial stream chronology comprising (a) braided rivers, partly nested with smallscale streams, (b) high-gradient straight streams, (c) low-gradient small-scale meander forms, (d) pronounced braided rivers, (e) large-scale meandering, and (f) large-scale vegetation-stabilized meandering forms and anabranching rivers. 7: Large-scale convex shapes in an overall concave longitudinal profile.

ous time-dependent factors and may therefore appear morphologically altered. In the study area near the Pangong Tso Lake, a maximum of four terrace orders was identified downstream. The comparable low number of terraces can be explained by the difference in climate and associated glacier oscillations between the study areas.

The sandurs also reflect the chronology of historical and recent landforms. In the investigated proglacial streams, sandurs formed a vertical sequence in wide valleys and a horizontal-vertical sequence in narrow valleys. However, due to sediment rearrangements and inputs, the sandurs could only be used as qualitative indicators of glacier oscillations. Therefore, sandurs need to be systematically reconstructed at different scales to exclude disruptive factors (Schumm and Lichty, 1965). Based on this methodology, it is possible to reconstruct relative chronologies.

Likewise, a sequence of proglacial stream patterns was identified in the study areas. Below the tongue of a glacier, the depositional sequence starts with braided river forms.
The landforms can be divided into high-gradient straight streams and low-gradient small-scale meander forms. Further downstream, pronounced braided rivers can be found in low-gradient streams of the sandur area. These landforms are followed by large-scale meandering stream patterns showing the same stream gradient. At considerable distances further downstream, large-scale vegetation-stabilized meandering forms and anabranching rivers characterize the proglacial river landscape in low-gradient streams. This sequence of proglacial streams can also be found in other high mountain areas, as illustrated by photographs of glacier forefields, e.g., by Röthlisberger (1986) and Winkler (2009).

Macroanalysis. Analysis of the longitudinal profiles of the proglacial streams allowed for the detection of local convex forms within an overall concave longitudinal stream profile of the proglacial streams. These convex shapes - some of these are aligned in steps - were created by sedimentation during past glacier fluctuations and can therefore be attributed to moraine stages. Subsequent erosion and accumu- 
lation processes influence the formation and rearrangement of these shapes in the longitudinal proglacial stream profile.

All of the morphological forms described above proved suitable to characterize the glaciofluvial and fluvial sequence of landforms in the glacier forefields of the Himalayas (Fig. 2). In summary, the aim of this work to develop a tool for establishing relative chronologies of glacier fluctuations was achieved through the detailed geomorphological analysis at the micro-, meso-, and macroscale that was carried out in this study. This new tool complements the conventional glacial indicators found in the Himalayas (Kuhle, 1990). It can be used to locate glacier forefields and distinguish different glacial stages in high mountain areas of the Himalayas, where conventional indicators are not well preserved. In addition, the geomorphological indicators used here can serve to compare the intensity of glacier-melting processes. In this way, they also allow for the detection of climatic changes in the proglacial streams of the high mountain areas under investigation. Thus, the outcomes of this study contribute to the understanding of streams in the Himalayas, which also has practical implications, as changes in their total runoff (Tombrink, 2017) may affect landscapes and irrigation systems.

Data availability. All data are publicly accessible via the thesis (dissertation online) and the references therein.

Competing interests. The author declares that there is no conflict of interest.

This open-access publication was funded by the University of Göttingen.

\section{References}

Kuhle, M.: The Probability of Proof in Geomorphology - an Example of the Application of Information Theory to a new Kind of Glacigenetic Morphological Type, the Ice-Marginal Ramp (Bortensander), GeoJ., 21.3, 195-222, 1990.

Kuhle, M.: The maximum Ice Age (Würmian, Last Ice Age, LGM) glaciation of the Himalaya - a glaciogeomorphological investigation of glacier trim-lines, ice thicknesses and lowest former ice margin positions in the Mt. Everest-Makalu-Cho Oyu massifs (Khumbu and Khumbakarna Himal) including informations on late-glacial, neoglacial, and historical glacier stages, their snowline depressions and ages, GeoJ., 62, 193-650, 2005.

Kuhle, M.: The Uplift of High Asia above the Snowline and its Glaciation as an Albedo-Dependent Cause of the Quaternary Ice Ages, Earth sciences in the 21st Century, Nova science publ., New York, USA, 2013.

Montgomery, D. R. and Buffington, J. M.: Channel-reach morphology in mountain drainage basins, Geol. Soc. Am. Bull., 109, 596-611, 1997.

Racoviteanu, A. and Bajracharya, S.: GLIMS Glacier Database, Boulder, CO, USA, National Snow and Ice Data Center, https://doi.org/10.7265/N5V98602, 2008.

Röthlisberger, F.: 10000 Jahre Gletschergeschichte der Erde: Ein Vergleich zwischen Nord- und Südhemisphäre Alpen, Skandinavien, Himalaya, Alaska, Südamerika, Neuseeland, Sauerländer, Aarau, Switzerland, 1986.

Schumm, S. A.: To interpret the earth: Ten ways to be wrong, Cambridge Univ. Press, Cambridge, UK, 1991.

Schumm, S. A. and Lichty, R. W.: Time, Space, and Causality in Geomorphology, Am. J. Sci., 263, 110-119, 1965.

Tombrink, G.: Flood events and their effects in a Himalayan mountain river: Geomorphological examples from the Buri Gandaki Valley, Nepal, J. Mt. Sci., 14, 1303-1316, 2017.

Winkler, S.: Gletscher und ihre Landschaften: Eine illustrierte Einführung, Wiss. Buchges., Darmstadt, Germany, 2009. 